Article

\title{
Livelihood Strategies in Shaxi, Southwest China: Conceptualizing Mountain-Valley Interactions as a Human-Environment System
}

\author{
Franz K. Huber ${ }^{1, *}$, Michael Morlok ${ }^{2}$, Caroline S. Weckerle ${ }^{3}$ and Klaus Seeland ${ }^{1}$ \\ 1 ETH Zürich, Institute for Environmental Decisions-Group Society, Environment and Culture, \\ Sonneggstrasse 33, 8092 Zürich, Switzerland; E-Mail: klaus.seeland@env.ethz.ch \\ 2 B,S,S. Volkswirtschaftliche Beratung, Steinenberg 5, 4051 Basel, Switzerland; \\ E-Mail: michael.morlok@bss-basel.ch \\ 3 Institute of Systematic Botany, University of Zürich, Zollikerstrasse 107, 8008 Zürich, Switzerland; \\ E-Mail: weckerle@ethnobot.ch \\ * Author to whom correspondence should be addressed; E-Mail: huber@ethnobot.ch; \\ Tel.: +41-44-634-84-17.
}

Academic Editor: Helmut Haberl

Received: 17 January 2015 / Accepted: 11 March 2015 / Published: 17 March 2015

\begin{abstract}
This paper investigates the socio-ecological differences and interactions between upland and lowland areas in Shaxi Valley, Yunnan Province, Southwest China. As an analytical tool we used an extended Human-Environment System Framework by focusing particularly on the dynamics and sustainability of livelihood strategies and mountain-valley interactions. Drawing from household surveys conducted in two mountain and two valley communities in 2005 and 2009, we show that the distinct income gap between mountain and valley households in 2005 ceased to exist in 2009. The main drivers for this development are the local tourist industry, persistent demand for forest resources, as well as local off-farm and seasonal migrant employment.
\end{abstract}

Keywords: education; ethnic minorities; migrant labor; natural resources; village networks; Yunnan 


\section{Introduction}

Lowland and upland regions throughout the world, but particularly in developing economies, are interlinked through complex socio-ecological interactions on various levels [1]. While economic development and societal change often start in the accessible lowlands, remote mountainous areas provide vital resources for these processes, such as natural resources, agricultural products, and labor surplus $[2,3]$. However, unsustainable land use practices such as commercial logging and agricultural intensification in mountainous areas have been claimed to have a negative impact on lowland areas and thus whole watersheds should be considered for the analysis of socio-ecological interactions in order to understand the rationale of the highland/lowland complementarity [4,5]. In Southwest China the Central Government of the PR China established large-scale environmental programs after the drought in the Yellow River basin in 1997 and heavy flooding along the Yangtze in 1998, namely the Natural Forest Protection Program (tianranlin baohu gongcheng), which bans logging along the Yangtze and Yellow River, and the Sloping Land Conversion Program (tuigeng huanlin gongcheng), which was introduced to provide economic incentives for farmers to promote the reforestation of erosion-prone farmland in the mountainous upper reaches of these rivers. As these policies had adverse impacts on local governments and households, tourism, off-farm labor, and the commercialization of natural resources other than timber have been promoted for economic development [6-9].

Few studies have taken Southwest China into account so far and provided a detailed analysis of these interactions at the household and community level. Therefore we focus on the livelihood system of an ethnic minority area where economic development and the resulting societal change are met with survival strategies that have been and still are being developed by basically agrarian communities.

Our research questions are: What factors and environmentally relevant decisions are structuring household livelihood activities and affecting the sustainability of local livelihoods? Are there modifications in these livelihood strategies in the current phase of socioeconomic change with particular respect to improved mobility and features of modernization? What are the major feedback loops between the lowland and upland areas and how might they influence the respective economic developments and their related societal changes? To answer these questions we use the Human-Environment System (HES) Framework, an analytical tool for conceptualizing coupled human-environmental systems [10]. The HES Framework depicts the multiple interacting social, economic, and ecological variables as well as feedback loop learning in land-use systems on a temporal and spatial scale [11].

\section{Methods}

\subsection{Study Area}

Shaxi Township $\left(26^{\circ} 14^{\prime}-26^{\circ} 24^{\prime} \mathrm{N}\right.$ and $\left.99^{\circ} 45^{\prime}-99^{\circ} 56^{\prime} \mathrm{E}\right)$ is located in a wide, flat valley at $2100 \mathrm{~m}$ a.s.l. surrounded by hills and mountain ranges with elevations up to $3300 \mathrm{~m}$ a.s.l. Shaxi belongs to Jianchuan County, Dali Bai Autonomous Prefecture, Yunnan Province, PR China, located in the south of the Hengduan Mountains [12] (Figure 1). The valley bottom is predominantly inhabited by the Bai ethnic group, while the mountains are sparsely populated mainly by the Yi, who migrated to Shaxi some 50 years ago $[13,14]$. 


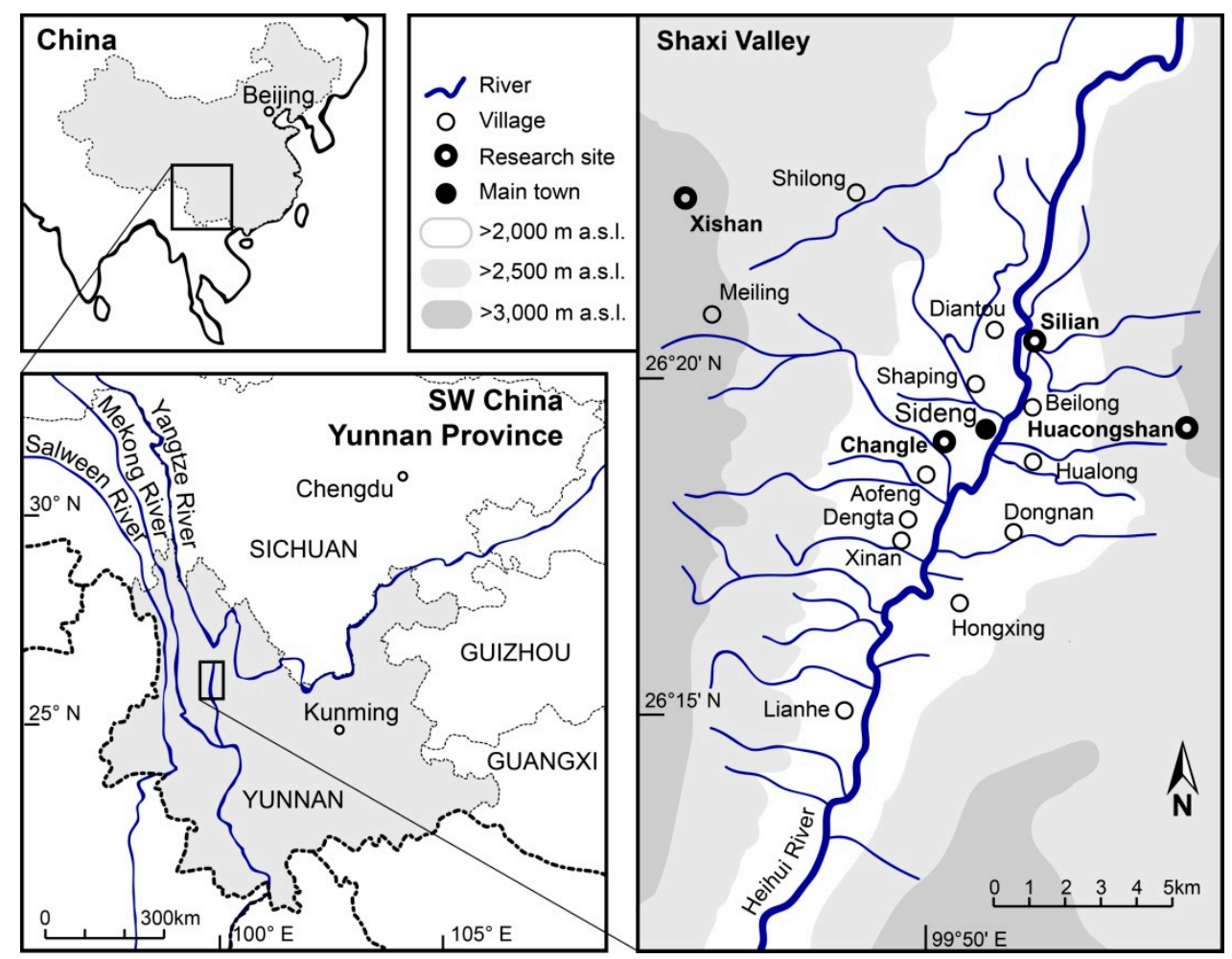

Figure 1. Shaxi Valley, Yunnan Province, Southwest China. Villages included in the survey are shown in bold.

The annual precipitation between 740 and $790 \mathrm{~mm}$ mainly occurs during the rainy season from June to September, and the mean annual temperature is $12.2^{\circ} \mathrm{C}$ [15]. The valley bottom is covered with paddy fields, the valley slopes are forested predominantly with pine, evergreen oak woods, and remnants of evergreen laurel forests in the more humid tributary valleys. The forests show high anthropogenic disturbance.

Shaxi, with its main town Sideng, has over the centuries developed into an important intermediate station and trading point along the "Tea and Horse Road" or "Southern Silk Road," a trading network for Chinese tea, sugar, and salt as well as Tibetan horses [16]. With the end of mule-based transportation after the establishment of the People's Republic of China in the middle of the 20th century, this supra-regional trade came to a sudden end, with major impact on Shaxi's economy [17]. The remoteness and an almost negligible economic development in the second half of the 20th century contributed to the exceptional preservation of Shaxi's cultural heritage and agriculturally-shaped landscape [18].

With its diverse ethnic and socioeconomic background and the recent development of tourism, Shaxi makes a suitable model for investigating socio-ecological interactions between lowland and upland communities related to livelihood strategies and household income generation.

In association with the Shaxi Valley Rehabilitation Project and its poverty alleviation program [18] a baseline survey of livelihood activities in Shaxi for the year 2005 was published [13]. The local economy was found to be predominantly based on agriculture, livestock breeding, and the collection and trade of non-timber forest products (NTFPs) such as mushrooms and medicinal plants. However, households deployed significantly different activities, namely non-timber forest product collection in the mountains and rice cultivation and trading of local products in the valley. Other income sources were temporary or permanent employment in construction projects, the regional industry, tourism, or public service. Annual household income is highly variable, and ranges from $2000 \mathrm{CNY}$ (294 USD) to more than 50,000 CNY 
(7535 USD) [13]. In 2005, household income in the mountain villages was significantly lower than in households located in the valley.

\subsection{Analytical Framework}

We use the Human-Environment System (HES) Framework [10] as the conceptual model for the analysis of the social-ecological system and its changes over time. The basic principles of the HES Framework are: (1) human and environmental systems are coupled and complementary; (2) both have hierarchical structures; (3) there are various interactions among and within different levels of human and environmental systems; (4) there are feedback loops within and between human and environmental systems; (5) human systems incorporate decision-making processes with various drivers; (6) human systems and decision-making processes build on different types of environmental awareness; and finally (7) the material and social environment of a coupled human and environmental system is the matrix and starting point of its analysis [10,19]. The strength of the HES Framework lies in its emphasis on interactions and interferences within and among different social levels and functional layers as well as an adaptive decision-making based on environmental feedback loop learning [11,20]. To build a suitable model for the analysis of socioeconomic and livelihood issues, we integrate the factors and variables used in the Sustainable Livelihoods Framework [21] to the HES Framework. Within this extended framework we use empirical data to characterize the most prominent interferences within and among layers of actors, assets, and livelihood strategies as well as relevant feedback loops to analyze mountain-valley interactions in Shaxi.

\subsection{Data Collection}

Household surveys were conducted in Shaxi Valley in September and October 2009 and data were collected in four villages (Figure 1), two located in the valley bottom (hereafter referred to as "valley"; Changle, $26^{\circ} 19^{\prime} 09^{\prime \prime} \mathrm{N}, 9^{\circ} 50^{\prime} 11^{\prime \prime} \mathrm{E}, 2120 \mathrm{~m}$ a.s.1. and Silian, 26 $20^{\prime} 31^{\prime \prime} \mathrm{N}, 99^{\circ} 51^{\prime} 47^{\prime \prime} \mathrm{E}, 2120 \mathrm{~m}$ a.s.1.; Bai ethnic group) and two located in the adjacent mountains (scattered households west of Shilong and Meiling, at around $26^{\circ} 23^{\prime} \mathrm{N}, 9^{\circ} 44^{\prime} \mathrm{E}, 2775-3070 \mathrm{~m}$ a.s.l. hereafter referred to as "Xishan," and Huacongshan, at around $26^{\circ} 19^{\prime} \mathrm{N}, 99^{\circ} 55^{\prime} \mathrm{E}, 2800-3010 \mathrm{~m}$ a.s.l.; Yi ethnic group). A total of $\mathrm{N}_{\mathrm{H}}=60$ households with $\mathrm{N}_{\mathrm{I}}=274$ individuals were included in the household survey by applying systematic random sampling (Changle: $\mathrm{n}_{H}=17$; Silian: $\mathrm{n}_{\mathrm{H}}=17$; Xishan: $\mathrm{n}_{\mathrm{H}}=13$; Huacongshan: $\mathrm{n}_{\mathrm{H}}=13$ ). Household surveys included semi-structured interviews, usually with the heads of the household, on the socioeconomic and socio-demographic situation (including household size, income sources and age, education, and occupation of all household members), land use (including land holding, cultivated crops, yields, income, and division of labor), and forest and forest product use and management (including collected species, amounts, collection intensity, collection sites, selling prices, and income). Interviews were carried out in Chinese with the assistance of an interpreter, and lasted from $20 \mathrm{~min}$ to $3 \mathrm{~h} 30 \mathrm{~min}$ (mean $=57 \mathrm{~min}, \mathrm{SD}=26 \mathrm{~min}$ ) each. Informal talks, participant observation, and semi-structured interviews with local village leaders and officials supplemented our data collection. Informed consent was given by the interviewees and involved authorities for the publication of the results. 
For the analysis of temporal developments of livelihoods, we compare these data with those collected in Shaxi in 2005 and published in Huber et al. [13]. For the comparison of incomes between 2005 and 2009, the values for 2005 have been adjusted for inflation [22].

Annual household cash income was defined according to answers by the interviewees about separate sources of income. Income sources have been classified as income from agriculture, non-timber forest products (NTFPs), logging, local off-farm employment within the township, and employment in the public service as well as migrant labor (outside the township for at least one month, see [23]). Income is reported as cash income in Chinese Renminbi (CNY; $1 \mathrm{USD}=6.8 \mathrm{CNY}$; October 1, 2009) and given as a percentage of each livelihood activity in relation to the total household cash income. When interviewees were reporting income ranges, the mean values were used. The term "subsistence income" is used to describe the cash equivalent value of subsistence production. It has been calculated by multiplying the crop yields for self-use by the local market price at the time of the survey.

Household income diversification has been measured using the Herfindahl index $(\mathrm{H})$, which is calculated using $\mathrm{H}=1-\Sigma_{\mathrm{i}} \mathrm{p}_{\mathrm{i}}{ }^{2}$, (for measuring diversity instead of concentration), where $\mathrm{p}$ indicates the percentage income of $\mathrm{i}=$ agricultural, NTFP, logging, public service, local off-farm, and migrant labor activities, with values closer to 0 showing lower and values closer to 1 showing higher household income diversity [24,25]. Income inequality at the village level has been calculated using the Gini coefficient, where a higher value means higher income inequality within a village [26].

Additionally, households both in the valley and in the mountain region have been stratified by their total income per capita into three equally sized groups (see Tables 3 and 4). Total income comprises total household cash and subsistence income.

Education was recorded by years of individual school attendance. At the household level it is calculated as the mean attendance of all members of each household as well as the years of attendance of the highest education per household.

Land area has been measured in the Chinese standard unit $m u$, which corresponds to $1 / 15$ of a hectare or $666.67 \mathrm{~m}^{2}$. In the valley villages, former communal agricultural land has been allocated and leased to individual households according to the household size with the economic reforms (gaige kaifang) in the early 1980s, in which the "Household Responsibility System" (jiating lianchan chengbao zerenzhi) was important. For more details on China's land tenure system and agricultural policy see [27,28]. In the mountains, forest land has been cleared unregulated on arrival of the Yi population, who immigrated from Ninglang in Lijiang Prefecture, Yunnan Province, between 1960 and 1990.

\subsection{Statistical Tools and Tests}

Analyses of variance (ANOVA) were used to compare villages and regions, to identify variables with significant village- and region-level differences, and to compare livelihood activities among the three income groups defined for mountain and valley households. The data were first tested for normal distribution using the Shapiro-Wilk test. A Levene test was used to detect whether the variances of the groups are homogeneous. In the case of normal distribution of the data, a one-way ANOVA was applied and followed by post hoc tests for multiple comparisons (Games-Howell test for variables with significantly different variances; Tukey's test for variables with homogeneous variance) to determine 
pairwise differences among the villages. In cases where a normal distribution could not be assumed, the Kruskal-Wallis test was used. The significance level $\alpha$ for all tests was 0.05 .

Stepwise multiple linear regressions were used to analyze the factors influencing the selection of livelihood activities. The regression model includes household income and the different income sources as response variables as well as the following 12 independent variables: "Household size" (\# of people); "highest education of a member of the household" (\# of years at school); "mean education of all members of the household" (\# of years at school); "total agricultural land area per capita in the household" $(\mathrm{mu})$; "number of elderly (> 65 y) residing in the household" (\# of people); "number of laborers (both on- and off-farm, male and female) in the household" (\# of people); dummy variables for the location of the household in the mountains or valley; and dummy variables for the village affiliation of the household. IBM SPSS Statistics 19 was used for all analyses.

\section{Results}

\subsection{Livelihood Strategies}

\subsubsection{At the Village Level}

Livelihoods in Shaxi are predominantly based on agriculture and the extraction of forest resources, such as medicinal plants, edible mushrooms, or timber from unlicensed small-scale logging. Off-farm employment and seasonal migrant labor are additional important income sources. The surveyed villages showed marked differences in structural and socio-demographic characteristics (Table 1) and in the livelihood activities pursued to earn an income (Table 2). While for some livelihood activities no clear distinction between the villages could be found (i.e., overall agricultural income per capita, income from local off-farm or migrant labor, or employment in public service), for others a clear mountain/valley divide was found. For instance, while the per capita income from forest resources is statistically significantly higher in the mountain villages (Mountains: $1332 \pm 1208 \mathrm{CNY}$; Valley: $120 \pm 228 \mathrm{CNY}$; independent samples $t$-Test, $p<0.001$ ), off-farm income per capita is significantly higher in valley villages (Mountains: $604 \pm 1025 \mathrm{CNY}$; Valley: $2241 \pm 3035 \mathrm{CNY}$; independent samples $t$-Test, $p=0.006$ ). In addition to the expected mountain/valley divide, however, several livelihood activities were found to be highly specific to single villages (timber in Xishan; tobacco in Silian; and in Huacongshan specific collective migrant labor to factories in Southern China).

Table 1 shows a low accessibility of the mountain villages in contrast to the surveyed villages in the valley bottom. Land holdings per capita are significantly larger in the mountains, whereas arable land in the valley bottom is limited but allows for two harvests per year. The average household cash income in all villages is statistically not significantly different. While the annual income of households in the valley bottom did not increase substantially (from an average of 18,750 $\pm 14,955 \mathrm{CNY}$ [adjusted for inflation: $21,500 \pm 17,155 \mathrm{CNY}]$ in 2005 to $21,765 \pm 14,615 \mathrm{CNY}$ in 2009), the average income of households in the mountains increased from $5850 \pm 4980 \mathrm{CNY}$ (adjusted for inflation: $6710 \pm 5710 \mathrm{CNY}$ ) in 2005 to $13,155 \mathrm{CNY} \pm 7005 \mathrm{CNY}$ in 2009. When calculated per capita, the differences between mountain and valley residents' income disappear altogether in the period between 2005 and 2009 (2005: valley: $3255 \pm 2270 \mathrm{CNY}$ [adjusted for inflation: $3730 \pm 2605 \mathrm{CNY}$ ]; mountains: $1185 \pm 820 \mathrm{CNY}$ [adjusted for inflation: $1360 \pm 940$ ]; 2009: valley: $4125 \pm 2900 \mathrm{CNY}$; mountains: $3615 \pm 2215 \mathrm{CNY}$ ). The relative 
importance of the different income sources for both regions did not change significantly between 2005 and 2009.

The level of income equality within the villages is likewise different between the villages (Figure 2) and does not show a clear mountain/valley divide. Xishan (mountains) and Silian (valley) have a more equal distribution of household income than the other villages.

In Shaxi, NTFPs are an open access resource, not only accessible for mountain households but also for the valley population. All stakeholders are aware of periods of intensive harvesting, especially of medicinal plants, but no clear rules to regulate collection activities have so far been established. However, in recent years around $10 \mathrm{mu}$ /capita of government forest land has been allocated to individual households, but so far to those in valley villages only. The goal of a long-term tenure system for forest land, similar to the system for agricultural land, is to motivate forest users to manage their lots in a sustainable way and create an additional and secure income source, instead of relying on open access to government land. However, hardly any household knows what is allowed to do on this forest land or even where exactly its plot is located. Another system, which is proposed and partially applied in adjacent areas, is the auction of whole mountains to wealthy individual contractors, who allow local villagers to collect NTFPs on their land on payment of a fee. Both systems restrict the mountain population's legal rights to use forest resources. Mountain farmers repeatedly mentioned that they are waiting for the program to include their land, so that they can afford to convert large areas of surplus fields back to forest or fruit tree plantations.

Tourism in Shaxi is focused on the central town of Sideng and the temples and grottoes in the nature reserve of nearby Shibaoshan. In the surveyed villages, tourism is not a relevant source of direct income. However, it generates indirect revenue for the more peripheral villages through increased demand for unskilled labor in construction, timber, and NTFP harvesting, as well as agricultural production. The importance of these income sources varies considerably between the villages (Table 2). While NTFPs represent an important income source for the households in both mountain villages, unlicensed and thus illegal small-scale logging of timber for the flourishing construction sector in Shaxi is restricted to Xishan only, due to its remoteness and thus weaker integration into the local societal and legal system. Huacongshan, by comparison, benefits from an increased demand for agricultural products (Table 1). Interviews with both government officials and farmers in Xishan indicated that if pressure on livelihood options, particularly logging, in the mountains increases, migration to new localities is likely to happen. This outcome is sought by neither of the parties, and some flexibility in the enforcement of the logging policy is thus intended. 
Table 1. Overview of structural and socio-demographic variables among four villages in Shaxi Valley, SW China.

\begin{tabular}{|c|c|c|c|c|c|}
\hline \multirow{2}{*}{ Variables } & \multicolumn{2}{|c|}{ Mountains } & \multicolumn{2}{|c|}{ Valley } & \multirow{2}{*}{ ANOVA/Kruskal-Wallis } \\
\hline & Xishan & Huacongshan & Changle & Silian & \\
\hline Accessibility ${ }^{1}$ & very low & low & very high & very high & $\mathrm{n} / \mathrm{a}$ \\
\hline Elevation $^{2}$ (m.a.s.l.) & $2987 \pm 85$ & $2908 \pm 82$ & $2125 \pm 6$ & $2124 \pm 7$ & $\mathrm{n} / \mathrm{a}$ \\
\hline Total No. of households & 33 & 92 & 199 & 311 & $\mathrm{n} / \mathrm{a}$ \\
\hline Average household size (\# of people) & $3.9 \pm 1.0^{\mathrm{a}}$ & $3.7 \pm 1.1^{\mathrm{a}}$ & $5.4 \pm 1.2^{b}$ & $5.5 \pm 1.2^{\mathrm{b}}$ & $\mathrm{F}=10.293, p<0.001$ \\
\hline Landholding per capita $(m u)$ & $2.21 \pm 0.87^{\mathrm{a}}$ & $10.35 \pm 6.67^{b}$ & $1.25 \pm 0.37^{\mathrm{c}}$ & $1.32 \pm 0.69^{\mathrm{c}}$ & $\mathrm{F}=26.963, p<0.001$ \\
\hline Education ${ }^{3,4}(y)$ & $2.97 \pm 2.98^{\mathrm{a}}$ & $3.76 \pm 3.99^{\mathrm{a}}$ & $8.77 \pm 5.00^{b}$ & $8.69 \pm 3.50^{b}$ & $\mathrm{~F}=23.863, p<0.001$ \\
\hline Education men ${ }^{3}(y)$ & $4.50 \pm 2.94^{\mathrm{a}}$ & $5.61 \pm 4.34^{\mathrm{a}}$ & $10.18 \pm 3.67^{\mathrm{b}}$ & $9.24 \pm 2.73^{b}$ & $\mathrm{~F}=13.676, p<0.001$ \\
\hline Education women ${ }^{3}(y)$ & $1.33 \pm 2.06^{\mathrm{a}}$ & $1.69 \pm 2.24^{\mathrm{a}}$ & $7.11 \pm 5.86^{\mathrm{b}}$ & $8.21 \pm 4.04^{b}$ & $\mathrm{~F}=14.345, p<0.001$ \\
\hline
\end{tabular}

Values are given as means and standard deviation. For pairwise comparison of means, a Tukey's post hoc test was used when the variances were similar, and a Games-Howell post hoc test was used for unequal group variances. Means sharing the same superscript letters are not significantly different from each other $(p<0.05)$ and thus can be grouped together. ${ }^{1}$ very low $=$ distant from any road $(>2 \mathrm{~km})$, with footpaths only; low = accessible by tractor and motorcycle; very high $=$ paved road and easily accessible with car and truck. ${ }^{2}$ Average elevation of the households included in the survey. ${ }^{3}$ For people above 18 years. ${ }^{4}$ Xishan: $n=31$; Huacongshan: $n=34$; Changle: $n=61$; Silian: $n=54$.

Table 2. Variables showing economic differences and commonalities between two Bai villages in the valley and two Yi villages in the mountains of Shaxi Valley, SW China.

\begin{tabular}{|c|c|c|c|c|c|}
\hline \multirow{2}{*}{ Variables } & \multicolumn{2}{|c|}{ Mountains } & \multicolumn{2}{|c|}{ Valley } & \multirow{2}{*}{ ANOVA/Kruskal-Wallis } \\
\hline & Xishan & Huacongshan & Changle & Silian & \\
\hline Subsistence income ${ }^{1}$ per capita $(C N Y)$ & $417 \pm 352^{\text {a }}$ & $1530 \pm 2023^{b}$ & $805 \pm 556^{\mathrm{a}, \mathrm{b}}$ & $854 \pm 499^{\mathrm{a}, \mathrm{b}}$ & $\mathrm{F}=2.588, p=0.062$ \\
\hline Total cash income per capita $(C N Y)$ & $2977 \pm 1057^{\mathrm{a}}$ & $4349 \pm 2820^{a}$ & $4317 \pm 3803^{a}$ & $3925 \pm 1552^{a}$ & $\mathrm{~F}=0.929, p=0.433$ \\
\hline$\%$ of subsistence income in total income per capita ${ }^{2}$ & $12.2 \pm 7.6$ & $23.3 \pm 22.4$ & $23.2 \pm 21.1$ & $20.2 \pm 15.9$ & $\chi^{2}=1.844, \mathrm{df}=3, p=0.605$ \\
\hline Overall agricultural income per capita $(C N Y)$ & $1121 \pm 681^{\mathrm{a}}$ & $2332 \pm 1296^{\mathrm{a}}$ & $1462 \pm 878^{a}$ & $2089 \pm 1797^{\mathrm{a}}$ & $\mathrm{F}=2.711, p=0.054$ \\
\hline$\%$ of total cash income ${ }^{3}$ & $38.5 \pm 19.5$ & $57.2 \pm 15.8$ & $46.1 \pm 23.1$ & $55.9 \pm 38.0$ & $\chi^{2}=4.555, \mathrm{df}=3, p=0.21$ \\
\hline —Tobacco income per capita $(C N Y)$ & $0^{\mathrm{a}}$ & $0^{\mathrm{a}}$ & $157 \pm 447^{b}$ & $911 \pm 1117^{\mathrm{c}}$ & $\mathrm{F}=7.239, p<0.001$ \\
\hline$\%$ of total cash income & 0 & 0 & $4.7 \pm 15.2$ & $23.2 \pm 27.9$ & $\chi^{2}=14.671, \mathrm{df}=3, p=0.002$ \\
\hline
\end{tabular}


Table 2. Cont.

\begin{tabular}{|c|c|c|c|c|c|}
\hline \multirow{2}{*}{ Variables } & \multicolumn{2}{|c|}{ Mountains } & \multicolumn{2}{|c|}{ Valley } & \multirow{2}{*}{ ANOVA/Kruskal-Wallis } \\
\hline & Xishan & Huacongshan & Changle & Silian & \\
\hline Overall forest resources income per capita $(C N Y)$ & $1549 \pm 887^{\mathrm{a}}$ & $1116 \pm 1467^{\mathrm{a}}$ & $165 \pm 232^{b}$ & $73 \pm 221^{b}$ & $\mathrm{~F}=11.272, \mathrm{p}<0.001$ \\
\hline$\%$ of total cash income & $52.1 \pm 25.1$ & $23.6 \pm 13.9$ & $8.3 \pm 15.1$ & $1.4 \pm 3.9$ & $\chi^{2}=37.539, \mathrm{df}=3, p<0.001$ \\
\hline -NTFP income per capita $(C N Y)$ & $734 \pm 475^{\mathrm{a}, \mathrm{b}}$ & $1116 \pm 1467^{\mathrm{a}}$ & $165 \pm 232^{b}$ & $73 \pm 221^{b}$ & $\mathrm{~F}=6.349, p=0.001$ \\
\hline$\%$ of total cash income & $24.0 \pm 14.2$ & $23.6 \pm 13.9$ & $8.3 \pm 15.1$ & $1.4 \pm 3.9$ & $\chi^{2}=30.971, \mathrm{df}=3, p<0.001$ \\
\hline - Logging income per capita $(C N Y)$ & $815 \pm 500^{a}$ & $0^{\mathrm{b}}$ & $0^{\mathrm{b}}$ & $0^{\mathrm{b}}$ & $\mathrm{F}=41.120, p<0.001$ \\
\hline$\%$ of total cash income & $28.1 \pm 15.5$ & 0 & 0 & 0 & $\chi^{2}=51.514, \mathrm{df}=3, p<0.001$ \\
\hline Overall off-farm income per capita $(C N Y)$ & $307 \pm 676^{\mathrm{a}}$ & $901 \pm 1186^{\mathrm{a}, \mathrm{b}}$ & $2690 \pm 3927^{b}$ & $1764 \pm 1651^{\mathrm{a}, \mathrm{b}}$ & $\mathrm{F}=2.843, p=0.046$ \\
\hline$\%$ of total cash income & $9.4 \pm 23.2$ & $19.2 \pm 20.4$ & $45.6 \pm 29.8$ & $42.6 \pm 37.5$ & $\chi^{2}=15.061, \mathrm{df}=3, p=0.002$ \\
\hline _Local off-farm income per capita & $0^{\mathrm{a}}$ & $58 \pm 208^{a}$ & $1123 \pm 2675^{a}$ & $343 \pm 680^{a}$ & $\mathrm{~F}=1.877, p=0.144$ \\
\hline$\%$ of total cash income & 0 & $1.7 \pm 6.2$ & $15.1 \pm 24.0$ & $7.6 \pm 16.3$ & $\chi^{2}=7.806, \mathrm{df}=3, p=0.05$ \\
\hline —Public service income per capita $(C N Y)$ & $122 \pm 441^{a}$ & $282 \pm 921^{a}$ & $820 \pm 1710^{\text {a }}$ & $555 \pm 1508^{a}$ & $\mathrm{~F}=0.830, p=0.483$ \\
\hline$\%$ of total cash income & $5.4 \pm 19.5$ & $7.1 \pm 20.5$ & $12.2 \pm 23.0$ & $11.1 \pm 30.1$ & $\chi^{2}=3.100, \mathrm{df}=3, p=0.376$ \\
\hline —Migrant working income per capita $(C N Y)$ & $185 \pm 666^{\mathrm{a}}$ & $562 \pm 982^{a}$ & $747 \pm 1220^{\text {a }}$ & $866 \pm 1090^{\text {a }}$ & $\mathrm{F}=1.173, p=0.328$ \\
\hline$\%$ of total cash income & $4.0 \pm 14.3$ & $10.4 \pm 13.5$ & $18.3 \pm 22.5$ & $23.9 \pm 30.8$ & $\chi^{2}=6.293, \mathrm{df}=3, p=0.098$ \\
\hline Gini coefficient & 0.178 & 0.303 & 0.384 & 0.218 & $n / a$ \\
\hline Average Herfindahl diversity index & 0.42 & 0.55 & 0.52 & 0.33 & $n / a$ \\
\hline
\end{tabular}

Values are given as means and standard deviation. For pairwise comparison of means, a Tukey's post hoc test was used when the variances were similar, and a Games-Howell post hoc test was used for unequal group variances. Means sharing the same superscript letters are not significantly different from each other $(p<0.05)$ and thus can be grouped together. " "Subsistence income" is the cash equivalent value of subsistence agriculture. ${ }^{2}$ Total income is both household cash and subsistence income together. ${ }^{3}$ Percentage income of a livelihood activity relative to the total household cash income. 


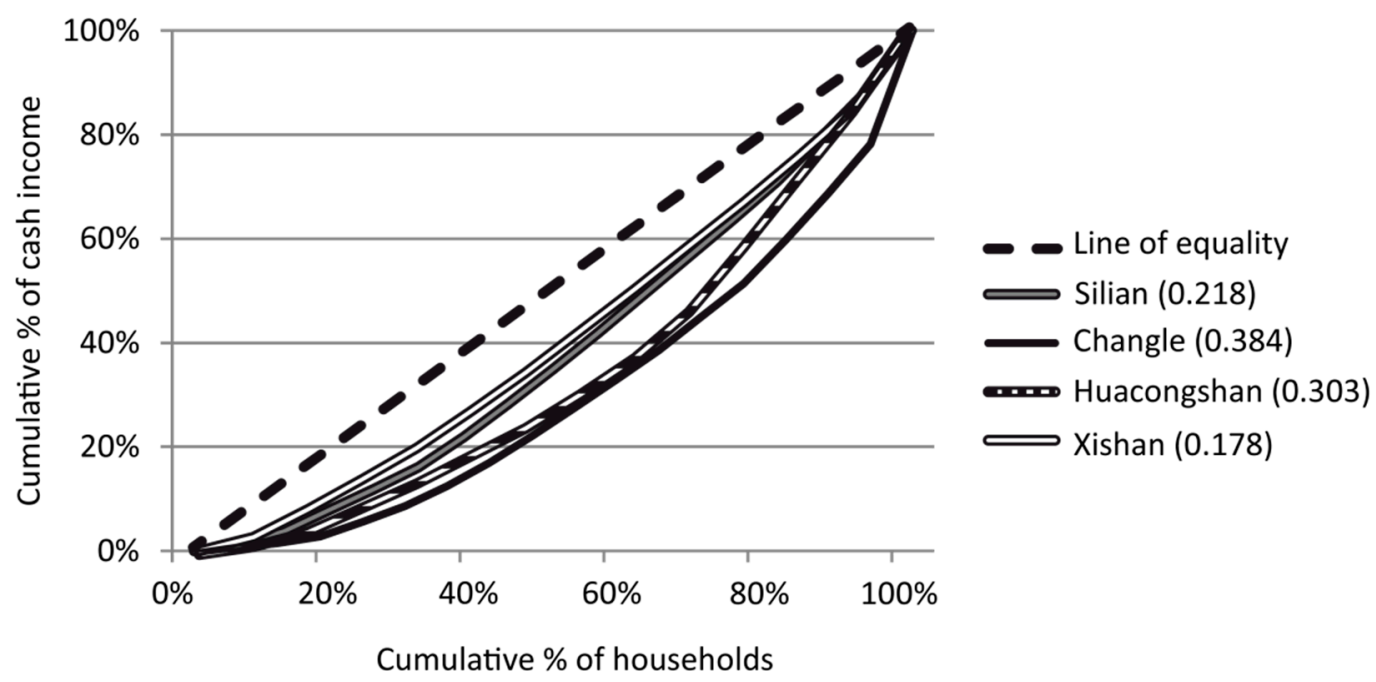

Figure 2. Comparison of income inequality (Lorenz curve and Gini coefficient) for the four villages surveyed. A higher Gini coefficient expresses higher income inequality within a village.

\subsubsection{At the Household Level}

Agriculture is practiced by a vast majority of households in Shaxi, both in the mountains and the valley for subsistence and cash income (Figure 3). In addition to agriculture, livelihood diversification is a key strategy. In the mountains, 96\% of all households participate in the collection of NTFPs, compared to $41 \%$ in the valley. When looking at the cash income from the sale of different NTFPs, the importance of edible mushrooms is evident, as $79.2 \% \pm 21.5 \%$ of the NTFP income of the households in the mountains and $73.2 \% \pm 40.5 \%$ in the valley derives from the marketing of mushrooms. Medicinal plants contribute $11.5 \% \pm 15.1 \%$ to the NTFP-income of the households in the mountains and $10.0 \% \pm 25.2 \%$ in the valley. The remaining NTFPs, such as wild orchids, small game, and wild food plants contribute $9.3 \% \pm 18.3 \%$ of NTFP-derived income for households in the mountains and $16.8 \% \pm 36.5 \%$ in the valley.
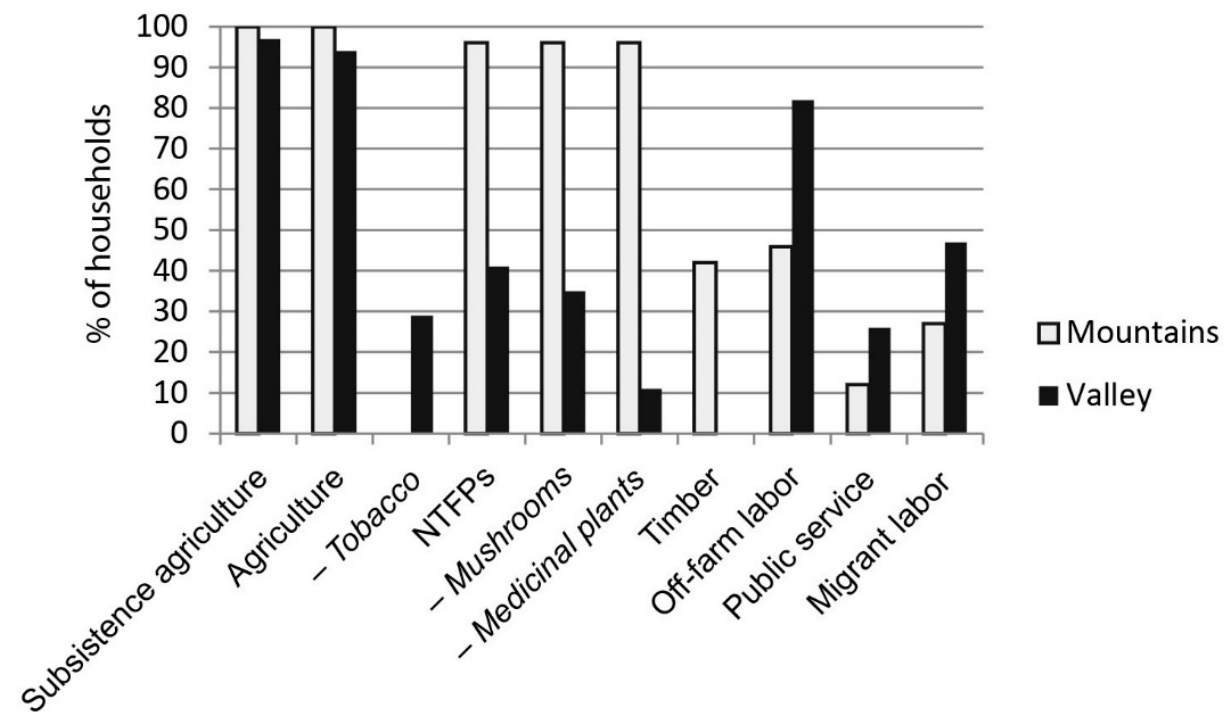

Figure 3. Share of households in the mountains and the valley participating in different livelihood activities. 
Table 3 shows socio-demographic variables for three income groups for both mountain and valley households. While most of the variables, in particular education and household income diversification (Herfindahl diversity index), do not show significant differences between income groups of the same region, a remarkable exception is the increase of landholding per capita from low-income to high-income households in the mountains. Table 4 examines economic variables for the three income groups of both regions. While in the valley wealth is not associated with agricultural and subsistence income, agricultural activities in the mountains positively correspond with wealth. In the valley it is predominantly the off-farm income that determines the wealth of a household.

Applying stepwise multiple linear regressions for the different livelihood activities, we clarify the patterns found in Table 2. While some of the livelihood activities are influenced by structural and socio-demographic variables such as education or the number of elderly persons living in the household, other activities are explained by the household location in the mountains or the valley, respectively, or its affiliation to a certain village (Table 5).

\subsubsection{At the Individual Level}

Off-farm income in Shaxi means well-paid and usually permanent jobs for higher educated people mainly from the valley's lowland (daily income: 50-70 CNY plus in kind benefits), as well as temporary jobs with a lower salary for unskilled laborers (30-50 CNY per day). As a consequence of these employment opportunities, the threshold of an expected daily income for laborers is set at about 40-50 CNY per day. People who do not have the opportunities to engage in these remunerative occupations, namely elderly people and women, rely on low-income jobs, predominantly the collection of NTFPs. The daily income is about $15 \mathrm{CNY}$ for medicinal plants and $22 \mathrm{CNY}$ for mushrooms (median of all indications), and sometimes even much lower.

The collection of NTFPs is equally distributed between the sexes (Table 6). The average age of NTFP collectors is significantly higher for collectors from the valley as compared to collectors from the mountains, both for mushrooms (independent samples $t$-Test, $p=0.015$; age valley $=45.3 \pm 9.3$; age $_{\text {mountains }}=33.8 \pm 14.0 ; n=45$ ) and medicinal plants (independent samples $t$-Test, $p=0.028$; age $_{\text {valley }}=47.8 \pm 12.9$; age mountains $\left.=33.1 \pm 13.4 ; n=24\right)$.

In contrast to the collection of NTFPs, off-farm work is clearly an occupation of young males with no significant difference between the age of off-farm laborers between the valley and the mountains (average age $=31 \pm 7.8 ; \min =17 ; \max =43 ; n=25$ ), while NTFP collection is performed by all age classes (average age $=36.7 \pm 14.0 ; \min =10 ; \max =70 ; n=69$ ). 
Table 3. Socio-demographic variables between three income groups (total income) in each the valley and the mountains of Shaxi Valley, SW China.

\begin{tabular}{|c|c|c|c|c|c|c|c|}
\hline \multirow[b]{2}{*}{ Variables } & \multicolumn{3}{|c|}{ Mountains } & \multicolumn{3}{|c|}{ Valley } & \multirow[b]{2}{*}{ ANOVA/Kruskal-Wallis } \\
\hline & $\begin{array}{c}\text { Low-Income } \\
\text { Group } \\
\end{array}$ & $\begin{array}{c}\text { Medium-Income } \\
\text { Group } \\
\end{array}$ & $\begin{array}{c}\text { High-Income } \\
\text { Group }\end{array}$ & $\begin{array}{c}\text { Low-Income } \\
\text { Group } \\
\end{array}$ & $\begin{array}{c}\text { Medium-Income } \\
\text { Group } \\
\end{array}$ & $\begin{array}{c}\text { High-Income } \\
\text { Group }\end{array}$ & \\
\hline Average household size (\# people) & $3.7 \pm 1.0^{\mathrm{a}}$ & $4.0 \pm 0.8^{\mathrm{a}}$ & $3.7 \pm 1.3^{\mathrm{a}}$ & $5.6 \pm 1.6^{\mathrm{b}}$ & $5.4 \pm 0.7^{b}$ & $5.0 \pm 0.8^{\mathrm{a}, \mathrm{b}}$ & $\mathrm{F}=6.457, p<0.001$ \\
\hline Landholding per capita $(m u)$ & $2.8 \pm 1.7^{\mathrm{a}}$ & $5.8 \pm 4.5^{\mathrm{a}, \mathrm{b}}$ & $10.2 \pm 8.3^{b}$ & $1.2 \pm 0.5^{\mathrm{a}}$ & $1.2 \pm 0.5^{\mathrm{a}}$ & $1.6 \pm 0.5^{\mathrm{a}}$ & $\mathrm{F}=8.869, p<0.001$ \\
\hline Average household education $(y)$ & $2.6 \pm 1.7^{\mathrm{a}}$ & $4.6 \pm 1.9^{\mathrm{a}, \mathrm{b}}$ & $3.0 \pm 1.9^{\mathrm{a}}$ & $7.6 \pm 2.3^{b, c}$ & $8.1 \pm 3.1^{\mathrm{c}}$ & $10.1 \pm 2.4^{\mathrm{c}}$ & $\mathrm{F}=16.856, p<0.001$ \\
\hline Highest education in household (y) & $5.2 \pm 3.4^{\mathrm{a}}$ & $6.7 \pm 2.3^{\mathrm{a}}$ & $5.6 \pm 5.1^{\mathrm{a}}$ & $10.6 \pm 4.1 \mathrm{a}, \mathrm{b}$ & $10.8 \pm 4.3^{\mathrm{a}, \mathrm{b}}$ & $13.1 \pm 3.6^{b}$ & $\mathrm{~F}=6.666, p<0.001$ \\
\hline Average Herfindahl diversity index & $0.46 \pm 0.15^{\mathrm{a}}$ & $0.51 \pm 0.15^{\mathrm{a}}$ & $0.49 \pm 0.21^{\mathrm{a}}$ & $0.35 \pm 0.22^{\mathrm{a}}$ & $0.43 \pm 0.17^{\mathrm{a}}$ & $0.50 \pm 0.17^{\mathrm{a}}$ & $\mathrm{F}=1.112, p=0.365$ \\
\hline
\end{tabular}

Values are given as means and standard deviation. For pairwise comparison of means, a Tukey's post hoc test was used when the variances were similar, and a Games-Howell post hoc test was used for unequal group variances. Means sharing the same superscript letters are not significantly different from each other $(p<0.05)$ and thus can be grouped together.

Table 4. Economic variables between three income groups (total income) in each the valley and the mountains of Shaxi Valley, SW China.

\begin{tabular}{|c|c|c|c|c|c|c|c|}
\hline \multirow[b]{2}{*}{ Variables } & \multicolumn{3}{|c|}{ Mountains } & \multicolumn{3}{|c|}{ Valley } & \multirow[b]{2}{*}{ ANOVA/Kruskal-Wallis } \\
\hline & $\begin{array}{c}\text { Low-Income } \\
\text { group }\end{array}$ & $\begin{array}{c}\text { Medium-Income } \\
\text { group }\end{array}$ & $\begin{array}{c}\text { High-Income } \\
\text { Group }\end{array}$ & $\begin{array}{c}\text { Low-Income } \\
\text { Group }\end{array}$ & $\begin{array}{c}\text { Medium-Income } \\
\text { Group }\end{array}$ & $\begin{array}{c}\text { High-Income } \\
\text { Group }\end{array}$ & \\
\hline Subsistence income ${ }^{1}$ per capita $(C N Y)$ & $331 \pm 189^{\text {a }}$ & $638 \pm 654^{\mathrm{a}, \mathrm{b}}$ & $1914 \pm 2313^{\mathrm{a}, \mathrm{b}}$ & $972 \pm 517^{\mathrm{a}, \mathrm{b}}$ & $796 \pm 450^{\mathrm{a}, \mathrm{b}}$ & $719 \pm 603^{\mathrm{a}, \mathrm{b}}$ & $\mathrm{F}=2.584, p=0.036$ \\
\hline Total cash income per capita $(C N Y)$ & $2367 \pm 633^{\text {a }}$ & $3041 \pm 934$ a,b & $5512 \pm 2765^{\mathrm{b}, \mathrm{c}}$ & $1904 \pm 949^{\text {a }}$ & $3734 \pm 689^{\mathrm{a}, \mathrm{b}, \mathrm{c}}$ & $6742 \pm 3518^{c}$ & $\mathrm{~F}=9.551, p<0.001$ \\
\hline Total income ${ }^{2}$ per capita $(C N Y)$ & $2698 \pm 283^{\mathrm{a}}$ & $3679 \pm 499^{a}$ & $7427 \pm 3723^{b}$ & $2876 \pm 743^{a}$ & $4530 \pm 573^{\mathrm{a}, \mathrm{c}}$ & $7461 \pm 3203^{b, c}$ & $\mathrm{~F}=10.909, p<0.001$ \\
\hline$\%$ of subsistence income in total income & $12.7 \pm 8.2$ & $18.1 \pm 18.3$ & $22.4 \pm 22.9$ & $36.0 \pm 22.8$ & $17.7 \pm 10.6$ & $11.5 \pm 10.4$ & $\chi^{2}=10.136, \mathrm{df}=5, p=0.071$ \\
\hline Overall agricultural income per capita $(C N Y)$ & $1124 \pm 441^{\text {a }}$ & $1332 \pm 607^{\mathrm{a}}$ & $2680 \pm 1518^{a}$ & $1286 \pm 980^{\mathrm{a}}$ & $1614 \pm 1093^{\mathrm{a}}$ & $2396 \pm 1879^{a}$ & $\mathrm{~F}=2.650, p=0.033$ \\
\hline$\%$ of total cash income & $47.4 \pm 15.9$ & $46.0 \pm 21.6$ & $50.0 \pm 23.5$ & $66.9 \pm 29.4$ & $44.6 \pm 29.6$ & $41.0 \pm 30.6$ & $\chi^{2}=4.940, \mathrm{df}=5, p=0.423$ \\
\hline — Tobacco income per capita $(C N Y)$ & $0^{\mathrm{a}}$ & $0^{\text {a }}$ & $0^{\text {a }}$ & $307 \pm 728^{b}$ & $700 \pm 993^{b}$ & $561 \pm 1,029^{b}$ & $\mathrm{~F}=1.995, p=0.094$ \\
\hline$\%$ of total cash income $e^{3}$ & 0 & 0 & 0 & $10.8 \pm 23.9$ & $20.6 \pm 29.0$ & $9.7 \pm 17.9$ & $\chi^{2}=9.790, \mathrm{df}=5, p=0.081$ \\
\hline Overall forest resources income per capita $(C N Y)$ & $1001 \pm 601^{\mathrm{a}, \mathrm{b}, \mathrm{c}}$ & $1263 \pm 598^{\mathrm{b}, \mathrm{c}}$ & $1725 \pm 1893^{\mathrm{c}}$ & $101 \pm 164^{\mathrm{a}}$ & $73 \pm 164^{a}$ & $187 \pm 323^{\mathrm{a}, \mathrm{b}}$ & $\mathrm{F}=7.093, p<0.001$ \\
\hline$\%$ of total cash income & $41.5 \pm 21.1$ & $42.8 \pm 22.9$ & $29.8 \pm 29.7$ & $9.1 \pm 17.9$ & $2.6 \pm 6.5$ & $3.2 \pm 5.8$ & $\chi^{2}=34.421, \mathrm{df}=5, p<0.001$ \\
\hline —NTFP income per capita $(C N Y)$ & $465 \pm 302^{\mathrm{a}, \mathrm{b}}$ & $938 \pm 349^{a, b}$ & $1373 \pm 1738^{b}$ & $101 \pm 164^{\mathrm{a}}$ & $73 \pm 164^{a}$ & $187 \pm 323^{\text {a }}$ & $\mathrm{F}=5.119, p=0.001$ \\
\hline$\%$ of total cash income & $19.3 \pm 11.1$ & $31.5 \pm 11.0$ & $21.4 \pm 16.7$ & $9.1 \pm 17.9$ & $2.6 \pm 6.5$ & $3.2 \pm 5.8$ & $\chi^{2}=31.707, \mathrm{df}=5, p<0.001$ \\
\hline
\end{tabular}


Table 4. Cont.

\begin{tabular}{|c|c|c|c|c|c|c|c|}
\hline \multirow[b]{2}{*}{ Variables } & \multicolumn{3}{|c|}{ Mountains } & \multicolumn{3}{|c|}{ Valley } & \multirow[b]{2}{*}{ ANOVA/Kruskal-Wallis } \\
\hline & $\begin{array}{c}\text { Low-Income } \\
\text { group }\end{array}$ & $\begin{array}{c}\text { Medium-Income } \\
\text { group }\end{array}$ & $\begin{array}{c}\text { High-Income } \\
\text { Group }\end{array}$ & $\begin{array}{c}\text { Low-Income } \\
\text { Group } \\
\end{array}$ & $\begin{array}{c}\text { Medium-Income } \\
\text { Group } \\
\end{array}$ & $\begin{array}{c}\text { High-Income } \\
\text { Group }\end{array}$ & \\
\hline —Logging income per capita $(C N Y)$ & $536 \pm 430^{\text {a }}$ & $325 \pm 440^{a}$ & $352 \pm 729^{a}$ & $0^{\mathrm{b}}$ & $0^{\mathrm{b}}$ & $0^{\mathrm{b}}$ & $\mathrm{F}=3.957, p=0.004$ \\
\hline$\%$ of total cash income & $22.2 \pm 18.6$ & $11.3 \pm 15.8$ & $8.4 \pm 18.0$ & 0 & 0 & 0 & $\chi^{2}=23.875, \mathrm{df}=5, p<0.001$ \\
\hline Overall off-farm income per capita $(C N Y)$ & $242 \pm 522^{\text {a }}$ & $446 \pm 834^{\text {a }}$ & $1107 \pm 1394^{\text {a }}$ & $517 \pm 671^{\text {a }}$ & $2047 \pm 1390^{\mathrm{a}, \mathrm{b}}$ & $4159 \pm 4442^{b}$ & $\mathrm{~F}=5.053, p=0.001$ \\
\hline$\%$ of total cash income & $11.2 \pm 23.2$ & $11.2 \pm 18.5$ & $20.2 \pm 24.7$ & $24.0 \pm 28.9$ & $52.8 \pm 32.0$ & $55.8 \pm 31.7$ & $\chi^{2}=18.828, \mathrm{df}=5, p=0.002$ \\
\hline — Local off-farm income per capita & $0^{\mathrm{a}}$ & $0^{\mathrm{a}}$ & $83 \pm 250^{\mathrm{a}}$ & $0^{\text {a }}$ & $538 \pm 839^{a}$ & $1695 \pm 3207^{\mathrm{a}}$ & $\mathrm{F}=2.305, p=0.057$ \\
\hline$\%$ of total cash income & 0 & 0 & $2.5 \pm 7.4$ & 0 & $13.8 \pm 21.2$ & $20.6 \pm 25.9$ & $\chi^{2}=18.117, \mathrm{df}=5, p=0.003$ \\
\hline —Public service income per capita $(C N Y)$ & $214 \pm 528^{\text {a }}$ & $0^{\text {a }}$ & $370 \pm 1,111^{a}$ & $172 \pm 513^{\text {a }}$ & $445 \pm 1,445^{\text {a }}$ & $1457 \pm 2189^{a}$ & $\mathrm{~F}=1.796, p=0.130$ \\
\hline$\%$ of total cash income & $10.0 \pm 23.5$ & 0 & $8.1 \pm 24.2$ & $7.0 \pm 20.9$ & $9.0 \pm 28.9$ & $19.1 \pm 29.2$ & $\chi^{2}=4.376, \mathrm{df}=5, p=0.497$ \\
\hline -Migrant working income per capita $(C N Y)$ & $28 \pm 83^{a}$ & $446 \pm 834^{a}$ & $654 \pm 1,167^{a}$ & $344 \pm 548^{\text {a }}$ & $1063 \pm 1084^{\mathrm{a}}$ & $1006 \pm 1533^{a}$ & $\mathrm{~F}=1.572, p=0.184$ \\
\hline$\%$ of total cash income & $1.1 \pm 3.3$ & $11.2 \pm 18.5$ & $9.6 \pm 15.5$ & $17.0 \pm 24.8$ & $30.0 \pm 31.1$ & $16.1 \pm 23.4$ & $\chi^{2}=7.799, \mathrm{df}=5, p=0.168$ \\
\hline
\end{tabular}

Values are given as means and standard deviation. For pairwise comparison of means, a Tukey's post hoc test was used when the variances were similar, and a Games-Howell post hoc test was used for unequal group variances. Means sharing the same superscript letters are not significantly different from each other $(p<0.05)$ and thus can be grouped together. ${ }^{1}$ "Subsistence income" is the cash equivalent value of subsistence agriculture. ${ }^{2}$ Total income is both household cash and subsistence income together. ${ }^{3}$ Percentage income of a livelihood activity relative to the total household cash income.

Table 5. Stepwise multiple linear regression for the different income sources as dependent variables.

\begin{tabular}{llll}
\hline Income Source & Explanatory Variable & B (T) & Summary of Model \\
\hline \multirow{2}{*}{ Total income ${ }^{1}$ per capita $(C N Y)$} & Intercept & $(2.392)^{*}$ & $R=0.515 ;$ Adjusted $R^{2}=0.238$ \\
& Total agricultural land/capita & $0.490(3.962) * * *$ & \\
\hline \multirow{2}{*}{ Total cash income per capita $(C N Y)$} & Household mean education level & $0.388(3.136) * *$ & \\
& Intercept & $(3.742)^{* * *}$ & $R=0.288 ;$ Adjusted $R^{2}=0.066$ \\
\hline
\end{tabular}


Table 5. Cont

\begin{tabular}{|c|c|c|c|}
\hline Income Source & Explanatory Variable & B (T) & Summary of Model \\
\hline \multirow{3}{*}{ Subsistence income ${ }^{2}$ per capita $(C N Y)$} & Intercept & $(4.184) * * *$ & $R=0.685 ;$ Adjusted $R^{2}=0.450$ \\
\hline & Total agricultural land/capita & $0.790(6.876)^{* * *}$ & \\
\hline & Mountain (dummy) & $-0.332(-2.891) * *$ & \\
\hline$\%$ of subsistence income in total income & $\begin{array}{c}\text { No statistically significant } \\
\text { explanatory variable }\end{array}$ & & $\mathrm{n} / \mathrm{a}$ \\
\hline \multirow{4}{*}{ Overall agricultural income per capita $(C N Y)$} & Intercept & $(4.996) * * *$ & $R=0.394 ;$ Adjusted $R^{2}=0.126$ \\
\hline & Total agricultural land/capita & $0.377(2.969) * *$ & \\
\hline & Silian (dummy) & $0.263(2.071) *$ & \\
\hline & Intercept & $(9.308) * * *$ & $R=0.430 ;$ Adjusted $R^{2}=0.156$ \\
\hline \multirow[t]{2}{*}{$\%$ of total cash income } & Household maximum education level & $-0.419(-3.172) * *$ & \\
\hline & Xishan (dummy) & $-0.380(-2.875) * *$ & \\
\hline \multirow{2}{*}{ — Tobacco income per capita $(C N Y)$} & Intercept & $(0.686)$ & $R=0.488 ;$ Adjusted $R^{2}=0.224$ \\
\hline & Silian (dummy) & $0.488(4.145)^{* * *}$ & \\
\hline \multirow{2}{*}{$\%$ of total cash income ${ }^{3}$} & Intercept & $(0.784)$ & $R=0.465 ;$ Adjusted $R^{2}=0.202$ \\
\hline & Silian (dummy) & $0.465(3.900) * * *$ & \\
\hline \multirow{3}{*}{$\begin{array}{l}\text { Overall forest resources income } \\
\text { per capita }(C N Y)\end{array}$} & Intercept & $(2.893) * *$ & $R=0.660 ;$ Adjusted $R^{2}=0.415$ \\
\hline & Mountains (dummy) & $0.391(3.085) * *$ & \\
\hline & Household size & $-0.349(-2.756) * *$ & \\
\hline \multirow{4}{*}{$\%$ of total cash income } & Intercept & $(5.116) * * *$ & $R=0.800 ;$ Adjusted $R^{2}=0.620$ \\
\hline & Xishan (dummy) & $0.524(5.499) * * *$ & \\
\hline & Household size & $-0.238(-2.566) *$ & \\
\hline & Household mean education level & $-0.237(-2.363) *$ & \\
\hline \multirow{3}{*}{ —NTFP income per capita $(C N Y)$} & Intercept & $(3.967) * * *$ & $R=0.552 ;$ Adjusted $R^{2}=0.279$ \\
\hline & Household size & $-0.409(-3.331) * *$ & \\
\hline & Huacongshan (dummy) & $0.247(2.014) *$ & \\
\hline
\end{tabular}


Table 5. Cont

\begin{tabular}{|c|c|c|c|}
\hline Income source & Explanatory Variable & $\mathbf{B}(\mathbf{T})$ & Summary of Model \\
\hline \multirow{3}{*}{$\%$ of total cash income } & Intercept & $(6.729) * * *$ & $R=0.636 ;$ Adjusted $R^{2}=0.382$ \\
\hline & Household mean education level & $-0.486(-4.141) * * *$ & \\
\hline & Household size & $-0.248(-2.111) *$ & \\
\hline \multirow{2}{*}{ —Logging income per capita $(C N Y)$} & Intercept & $(0.000)$ & $R=0.830 ;$ Adjusted $R^{2}=0.684$ \\
\hline & Xishan (dummy) & $0.830(11.051) * * *$ & \\
\hline \multirow{2}{*}{$\%$ of total cash income } & Intercept & $(0.000)$ & $R=0.856 ;$ Adjusted $R^{2}=0.728$ \\
\hline & Xishan (dummy) & $0.856(12.282) * * *$ & \\
\hline \multirow{3}{*}{ Overall off-farm income per capita $(C N Y)$} & Intercept & $(-1.457)$ & $R=0.609 ;$ Adjusted $R^{2}=0.348$ \\
\hline & Household mean education level & $0.426(3.585)^{* * *}$ & \\
\hline & Old persons in household & $0.292(2.459) *$ & \\
\hline \multirow{3}{*}{$\%$ of total cash income } & Intercept & $(-0.857)$ & $R=0.669 ;$ Adjusted $R^{2}=0.427$ \\
\hline & Household maximum education level & $0.534(4.934) * * *$ & \\
\hline & Old persons in household & $0.254(2.349) *$ & \\
\hline \multirow{3}{*}{ —Local off-farm income per capita } & Intercept & $(-1.733)$ & $R=0.493 ;$ Adjusted $R^{2}=0.215$ \\
\hline & Old persons in household & $0.295(2.266) *$ & \\
\hline & Household mean education level & $0.290(2.222) *$ & \\
\hline \multirow{2}{*}{$\%$ of total cash income } & Intercept & $(-1.307)$ & $R=0.423 ;$ Adjusted $R^{2}=0.164$ \\
\hline & Household mean education level & $0.423(3.465) * * *$ & \\
\hline \multirow{4}{*}{$\begin{array}{l}\text {-Public service income per capita } \\
(C N Y)\end{array}$} & Intercept & $(-3.791) * * *$ & $R=0.684 ;$ Adjusted $R^{2}=0.438$ \\
\hline & Household maximum education level & $0.567(4.486) * * *$ & \\
\hline & Old persons in households & $0.445(4.015) * * *$ & \\
\hline & Dummy mountains & $0.326(2.530) *$ & \\
\hline \multirow{4}{*}{$\%$ of total cash income } & Intercept & $(-3.163) * *$ & $R=0.613 ;$ Adjusted $R^{2}=0.341$ \\
\hline & Old persons in household & $0.412(3.437) * * *$ & \\
\hline & Household maximum education level & $0.515(3.756) * * *$ & \\
\hline & Dummy mountain & $0.357(2.556) *$ & \\
\hline
\end{tabular}


Table 5. Cont

\begin{tabular}{cccc}
\hline Income Source & Explanatory Variable & B (T) & Summary of Model \\
\hline -Migrant working income per capita $(C N Y)$ & No statistically significant explanatory variable & $\mathrm{n} / \mathrm{a}$ \\
\cline { 2 - 3 }$\%$ of total cash income & Intercept & $(-5.672) * * *$ & $R=0.408 ;$ Adjusted $R^{2}=0.136$ \\
& Dummy mountain & $-0.432(-3.187) * *$ \\
& Old persons in household & $-0.274(-2.022) *$ \\
\hline
\end{tabular}

Regression models includes the following independent variables: Household size (\# of people); highest education of a member of the household (y); mean education of all members of the household (y); laborers in the household (\# of people); old persons in the household (\# people); total agricultural land area per person in the household (mu); dummy variables for the location of the household in the mountains or the valley respectively; and dummy variables for the village affiliation of the households. Only the statistically significant variables $(p<0.05)$ in each regression model are mentioned (* $p \leq 0.05, * * p \leq 0.01, * * * p \leq 0.001$ significantly correlated). ${ }^{1}$ Total income is both household cash and subsistence income together. ${ }^{2}$ "Subsistence income" is the cash equivalent value of subsistence agriculture. ${ }^{3}$ Percentage income of a livelihood activity relative to the total household cash income.

Table 6. Gender distribution of mushroom and medicinal plant collection as well as off-farm employment.

\begin{tabular}{ccccc}
\hline \multirow{2}{*}{ Location } & Sex of Collectors & Mushrooms & Medicinal Plants & Off-Farm \\
\hline \multirow{2}{*}{ Valley } & Male & $45 \%$ & $50 \%$ & $89 \%$ \\
\cline { 2 - 5 } & Female & $55 \%$ & $50 \%$ & $11 \%$ \\
\hline \multirow{2}{*}{ Mountains } & Male & $44 \%$ & $44 \%$ & $100 \%$ \\
\cline { 2 - 5 } & Female & $56 \%$ & $56 \%$ & $0 \%$ \\
\hline
\end{tabular}




\subsection{Education}

Education levels show a strong divide between the mountains and the valley (Table 1), with a positive correlation between accessibility and the individual education level (Spearman-rho $\rho=0.573, p<0.001$, $\mathrm{n}_{\mathrm{I}}=180$ ). Regarding the households, the mean education level (Spearman-rho $\rho=0.743, p<0.001$, $\left.\mathrm{n}_{\mathrm{H}}=57\right)$ is more strongly correlated with accessibility than the highest education of anyone in the household (Spearman-rho $\rho=0.646, p<0.001, \mathrm{n}_{\mathrm{H}}=57$ ). We found a negative correlation between age and education in the valley (Pearson $\mathrm{r}=-0.344, p<0.001, \mathrm{n}_{\mathrm{I}}=108$ ), but not in the mountains (Pearson $\left.\mathrm{r}=-0.043, p=0.742, \mathrm{n}_{\mathrm{I}}=62\right)$. A negative correlation between education and age in the valley was found with the female population, $\left(\mathrm{r}=-0.644, p<0.001, \mathrm{n}_{\mathrm{I}}=51\right)$, whereas men did not show this pattern $\left(\mathrm{r}=-0.096, p=0.477, \mathrm{n}_{\mathrm{I}}=57\right.$ ). No statistical significance could be found in the mountains, neither for women nor men. Figure 4 shows the trend for average school education for men and women born between 1930 and 1998 (divided into age classes of 10 years), both in the valley and the mountains. The data show a rising education level in the valley, especially for women, finally equaling that of men. In the mountains, we do not see increased education over the past decades nor the equalization of male and female education levels.

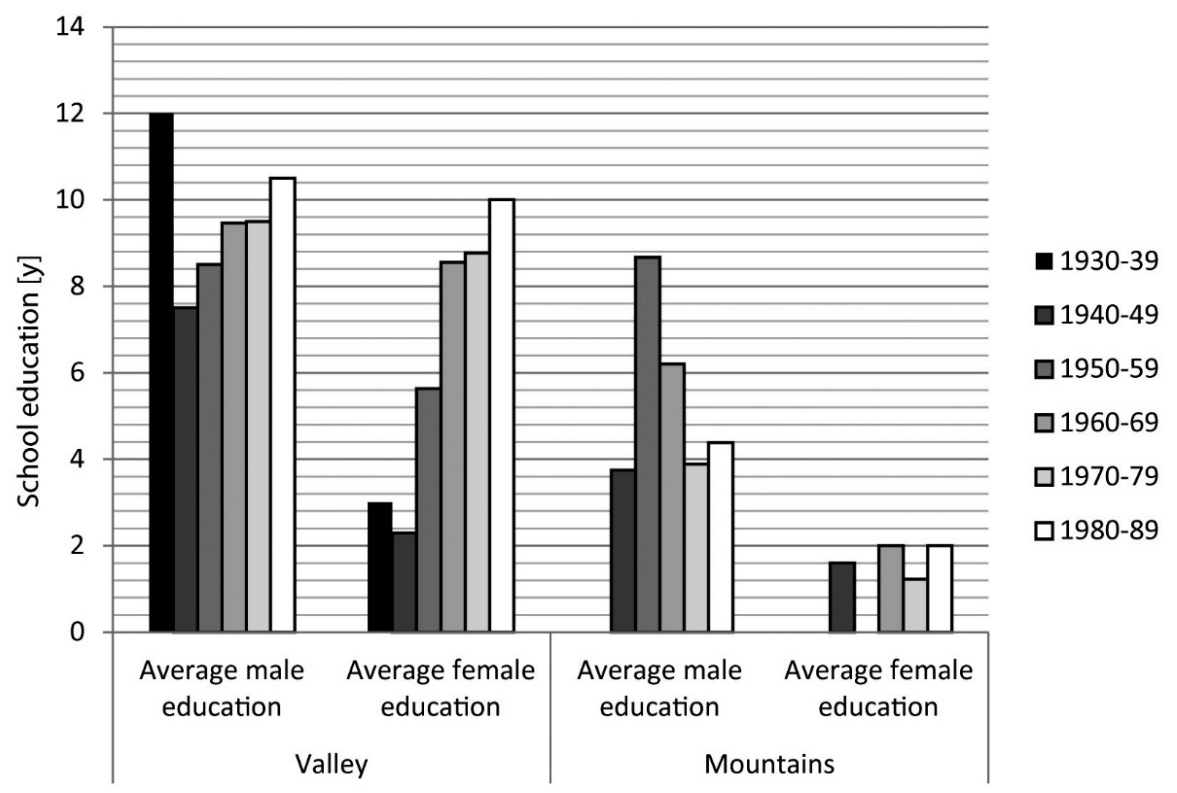

Figure 4. Average school education for Shaxi inhabitants born between 1930 and 1998 (divided into age classes of 10 years). For the mountains, no data are available for people born between 1930 and 1939, as only young Yi people started to move into Shaxi after 1960. $\mathrm{n}_{\text {Valley }}=115, \mathrm{n}_{\text {Mountains }}=65$.

\subsection{Depiction of the Main Mountain-Valley Interactions in a Simplified Model}

According to the HES Framework, we construct a simplified model of demand and supply patterns of the mountain-valley system of Shaxi and beyond (Figure 5), in which the main drivers are the demand for forest resources and labor supply for the increasing tourism in the valley, the nationally and internationally increasing demand for medicinal plants and edible mushrooms (mainly Tricholoma matsutake and Boletus spp., see [13]), as well as job opportunities in urban centers all over China. 
Tourism shows a prominent effect on local forest resources, as the restoration of the historic center of Sideng town and the surrounding villages in a traditional style as well as the increased living standard of the local population led to a higher demand for timber and charcoal. However, as logging is strictly regulated and limited under the current Natural Forest Protection Program, the supply of timber is a bottleneck and causes high prices. Unlicensed harvesting creates income opportunities for peripheral residents, i.e., mountain households. The model shows the importance of intermediaries located in the more central lowlands for connecting the supply of goods and services from remote mountain areas with the demand of national and international markets. The model also supposes that the withdrawal of resources from the human-environmental system in the mountains, i.e., logging and labor leaving for off-farm jobs, has negative feedback effects that affect the sustainability and resilience of the mountain subsystem through possible degradation of the forests and a decrease in agricultural production. This in turn feeds back on the mountain-valley system as a whole.

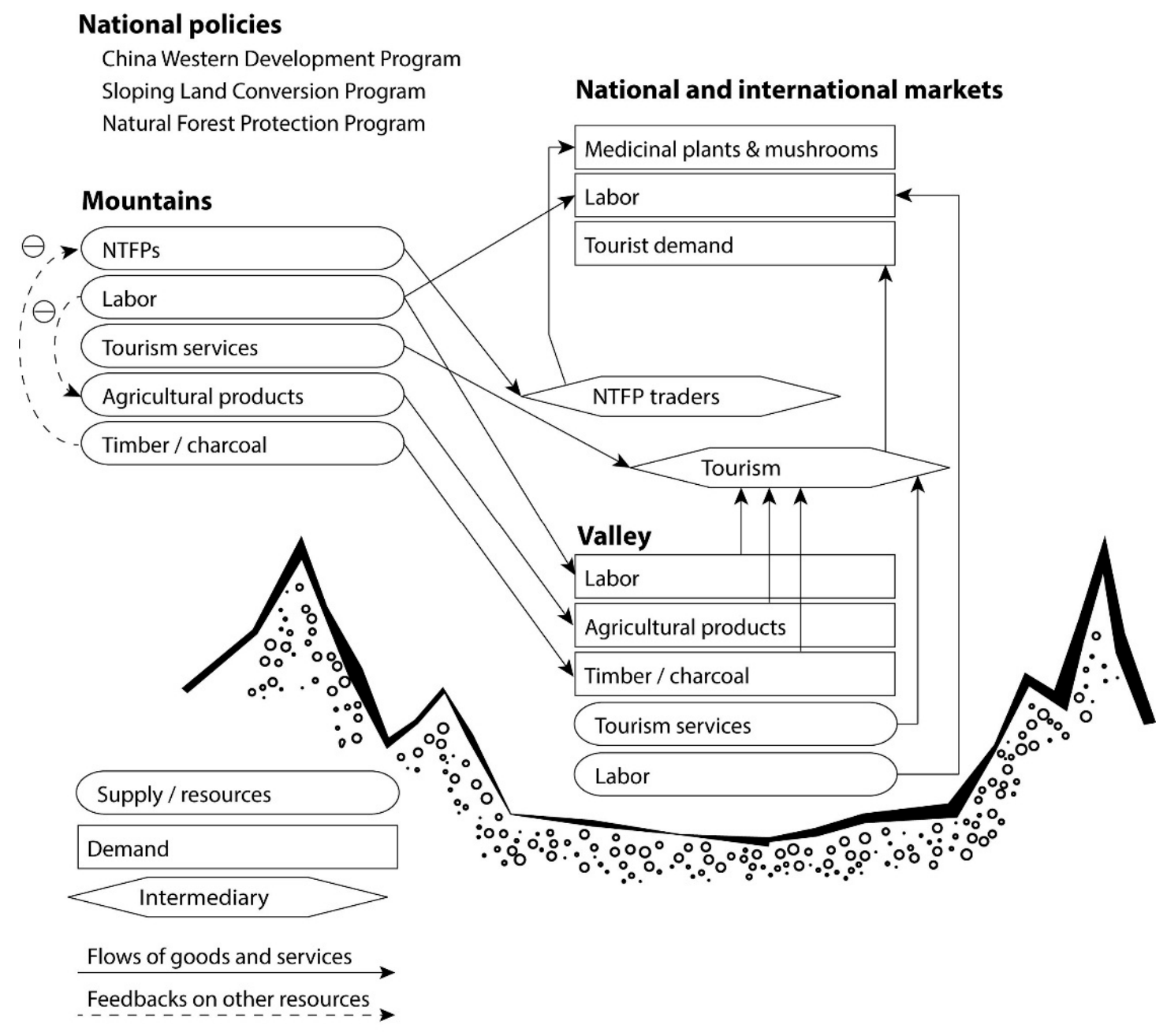

Figure 5. Model of relevant relationships between the valley and the mountains with national and international markets as the main drivers, and under the influence of national policies. Flow of cash and consumer goods is not shown. 


\section{Discussion}

\subsection{Structuring the Data with the HES Framework}

Using the HES Framework [10,11] and the variables used in the Sustainable Livelihoods Framework [21] (see [29] for an in-depth comparison of different frameworks for analyzing social-ecological systems) to structure our data, we define mountain and valley areas as the principal analytical units of the human-environment system of Shaxi. They are represented by social layers, where decision processes take place, as well as available assets for social actors. Social layers and assets are connected through the "linking" layers of applicable livelihood strategies. Livelihood strategies thus have a central position and intermediary function in our analytical framework. All these layers are linked by highly developed interferences and are embedded in a context of relevant policies and market forces, which we define as context layers (Figure 6). Dynamic aspects, such as changing households' livelihood strategies, community development, and the sustainability or resilience of the system, are described as primary (direct) and secondary (indirect) feedback loops and as a function of the interferences between the different layers. Decisions about livelihood activities and strategies are made on the individual and household level, influenced by the availability of exploitable natural resources, social, human, physical, and financial capital, as well as formal and informal institutions and policies above the household level. The HES Framework describes learning and decision processes as part of feedback loops within and among the different layers of human-environment systems. Accordingly, we will discuss the dynamics of livelihood decision processes by describing these feedback loops. We consider the resilience of the human-environment system to be "the capacity of a system to absorb disturbance and reorganize while undergoing change so as to still retain essentially the same function, structure, identity, and feedbacks" [30], and in accordance with the HES Framework as an interconnectedness of different social levels and various coexistent layers linked by feedback-loop learning.

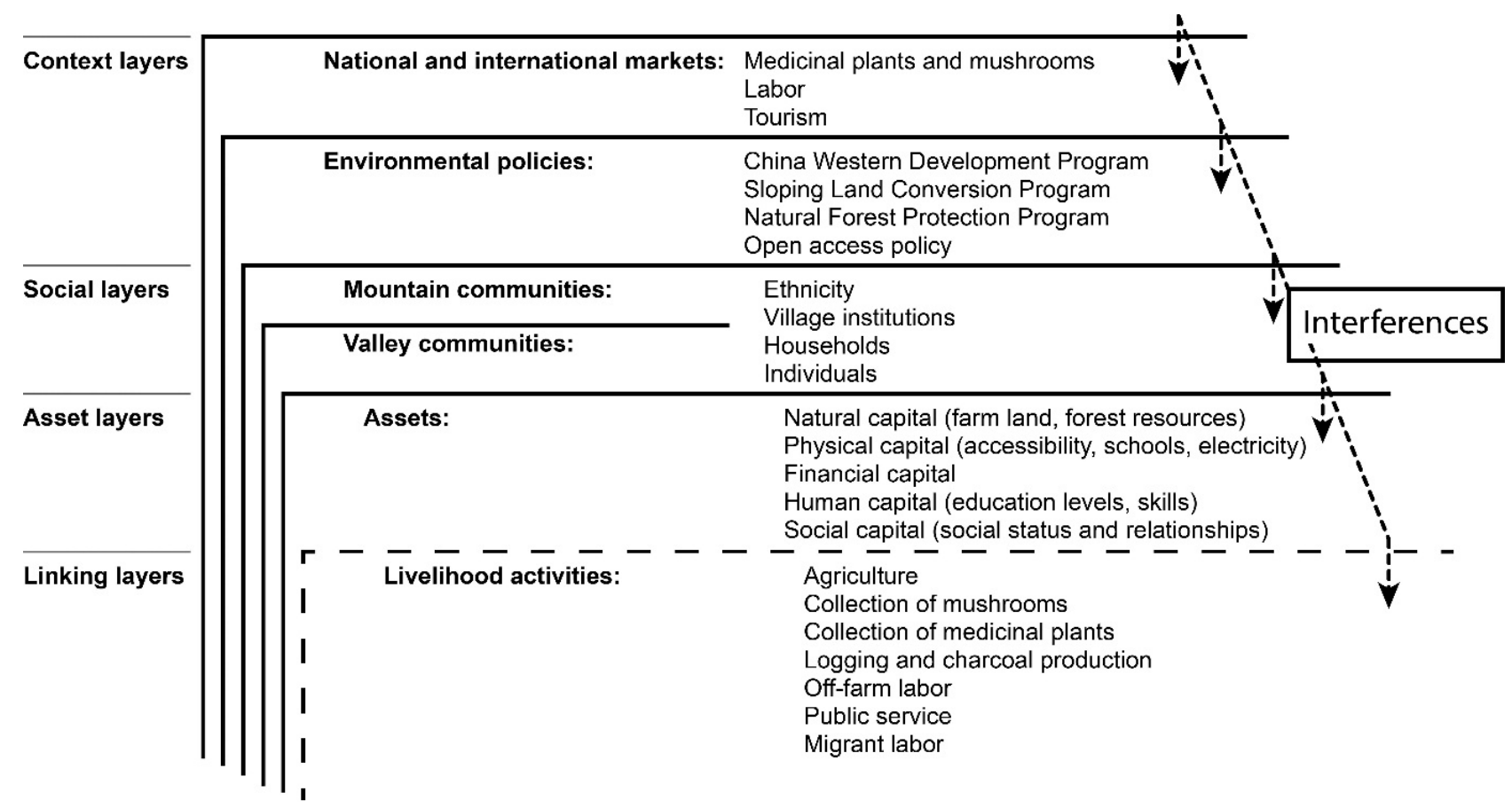

Figure 6. Definition of the different layers in the extended HES Framework. 


\subsection{Socioeconomic and Political Status of Mountain and Valley Communities}

The clear mountain/valley divide for the per capita income from non-timber forest products (NTFPs) found in the 2005 survey [13] was confirmed in that of 2009. No differences could be found between the mountain and valley villages in per capita income from agriculture, migrant labor, or working in public service. In contrast to the 2005 survey, the average household's cash income among all villages was found not to be significantly different, meaning that household income in the mountains almost equaled that of the valley households within a short period of four years. While in the past potatoes were the most important crop produced by the Yi communities in the mountains, now with increasing tourism in the valley, the demand for other goods and services from the mountains, such as construction materials, charcoal and fuel wood, NTFPs, agricultural products, and labor increased substantially.

However, there is a gap in the socioeconomic and political status between the valley and mountain populations as they are unequally integrated in the current government policies such as the Natural Forest Protection Program or the Sloping Land Conversion Program, where only households from the valley are entitled to own plots of forest land. This happens despite a broad consensus among all stakeholders that the most effective way to protect forest resources is to support the mountain population with programs for alternative income sources, such as the cultivation of high-value medicinal plants [13]. The neglect of the mountain farmers is further illustrated by the fact that the national Sloping Land Conversion Program only applies to valley farmers, although the erosion problems of farmland apparently exist primarily on the steep mountain slopes.

The Yi settled in the mountains around Shaxi after 1960, emigrating from problematic living conditions in their previous settlements further north. These Yi form communities with a high internal social cohesion but with relatively weak ties to the land that they currently cultivate and weak social and economic relations to the neighboring communities in the valley bottom. This could explain the low income disparity in Xishan, where logging ensures that the community remains self-reliant (stabilizing feedback loop), but it does not explain the striking contrast to Huacongshan, which has a much higher income disparity. In Huacongshan, more intensive off-farm work has altered some of the close intra-community social ties. As a consequence, more livelihood decisions are made at the level of individual households rather than at the level of the entire village, which leads to a higher diversity of income sources in the village and eventually to an increased income disparity.

The HES Framework describes this pattern as strong interferences between different social actors, assets, and linking layers, as well as positive feedback loops, which potentially decrease the stability of the system. The differences in income disparity for the villages in the valley might similarly be explained by the fact that in Silian a focus on agricultural production and particularly the cultivation of tobacco requires high intra-community cooperation to reduce transaction costs, while in Changle both the diversity of income sources and the income disparity is much higher. Village networks allow households to obtain market information - for example, market prices or the conditions of migrant labor in a far-away costal town - much more easily. The desire to keep information costs low explains why individuals and households in the same village would lean towards performing the same or similar activities. In villages with a higher income disparity, however, we find a higher diversity of income sources and thus more individualized decision-making processes relating to individual households' livelihood strategies, leading to more specialized households and more heterogeneous village structures. 


\subsection{Education and Livelihood Strategies}

Education and household income seem to be linked in the valley, where average household income and the highest level of education of a member of the household increases from low- and medium income to high income households (Table 3). This correlation is not found in the mountain villages. The regression analysis shows that the household mean education level is negatively correlated with the percentage income of NTFPs and forest resources in general (Table 5), but positively correlated with the total income (total cash income as well as off-farm income) per capita. Household maximum education, for comparison, is negatively correlated with the percentage of income from agriculture, but positively correlated with per capita income from public service and with the percentage of income from public services as well as off-farm income that contributes to the households' total cash income. For valley households, the availability of a large variety of assets, especially physical, financial, human, and social capital, has led to further investment in school education as a rewarding feedback loop for securing and improving livelihoods over time in a sustainable way [31]. Agricultural production, however, continues to be a mainstay in livelihood security, and forest resources represent an additional layer and fallback position for income generation. The access to resources is much more limited for households in the mountains, which have poor access to most assets except forest resources. Thus investment in education is inherently difficult and does not result in significantly better livelihood outcomes. Feedback-loop learning favors livelihood strategies based on the exploitation of forest resources, which are less costly and currently yield incomes similar to the livelihood activities in the valley. Migrant labor of mountain inhabitants relies largely on cheap and unskilled labor, which does not depend on school education. Both livelihood strategies, exploiting forest resources and migrant labor, provide a good short-term livelihood outcome, but are at the same time highly vulnerable and not sustainable: migrant labor has been shown to be unsecure [32]; forest resources, such as medicinal plants, are prone to overharvesting [13], and timber harvesting is illegal. Edible mushroom prices are subject to fluctuations in international markets as well as to annually varying weather conditions [13].

Education has shown complex effects on livelihood strategies elsewhere in China. While in the Tibetan Shuiluo Valley, Sichuan Province, the highest education in the household is not correlated with any livelihood strategy, the mean household education level is negatively correlated with the percentage of income from gold prospecting, but positively correlated with the percentage of income from public service employment to the households' total cash income. Education is generally correlated with higher total cash income [33]. The contrasting role of education in livelihood strategies, especially migration, has also been found by Démurger et al. [23] in Northern China, where a higher education level increased the likelihood of local off-farm employment but did not influence migration decisions. Finally, Harrell and Aga [34] found two contrasting trends in education decisions in ethnic minority areas of Southwest China. Firstly, some households invest in the best available education for the young generation; secondly, other children leave school before finishing the officially required nine years of compulsory education in order to emigrate for low-skilled jobs. In Shaxi, this pattern corresponds largely with valley and mountain households. 


\subsection{Diversity of Livelihood Strategies in Mountain and Valley Communities}

Most household livelihoods were found to be diversified, which is a common pattern in mountain environments [33,35-37]. The importance of agriculture to mountain households is shown in Table 4, illustrating that the percentage of subsistence income as a proportion of their total income is $12.7 \%$ in low-income households and $22.4 \%$ in high-income households. The reverse pattern has been found in valley households, where low-income households earn $36.0 \%$ of total income from subsistence agriculture, but high-income households only $11.5 \%$. For wealthy households in the valley, subsistence agriculture thus only represents a sideline in livelihood activities, while in the mountains wealthy households tend to invest more resources in subsistence production. This is due to the limitation of arable land and to the better availability of remunerative off-farm income opportunities for valley households. In the mountains, wealthy households manage significantly larger land holdings, leading to a higher absolute and relative income from subsistence agriculture.

Our data indicate that in the valley, the low-income households tend to have fewer income sources than high-income households. This is in accordance with Démurger et al. [23], who found off-farm diversification to be much lower in poor households as compared to richer households, but who also did not find a statistically significant correlation between the household members' education and livelihood diversification.

\subsection{The Role of NTFP Collection in Mountain and Valley Communities}

With respect to the collection of NTFPs, the results of this study revealed unexpected patterns. The household size was negatively correlated with the per capita income from selling NTFPs. This is in contrast to Hedge and Enters [38], who found a positive correlation between household size and NTPF income in Tamil Nadu, India. The difference might be explained by the fact that in Shaxi usually only one or few people per household without other engagement take part in the collection of NTFPs, while in the Indian case study the efficiency of NTFP collection benefits from teamwork within the household. However, our study finds, similarly to Hedge and Enters [38], a negative correlation between the household members' education and the percentage of income from NTFPs, which results in a decreasing dependence on forest resources for households with a higher average level of education. Poorer households did not show a higher relative dependence on NTFPs, as found in several other studies, e.g., [33,38,39]. NTFPs tend to be a dominant income source for households with few male members and older people or, in economically difficult times, as a backup strategy. However, the lack of a clear legal system of property and user rights obstructs sustainable management of NTFP resources and thus sustainable livelihoods in the long term [40].

We did not find a gender or age stratification in NTFP collection activities. One reason can be that medicinal plant collection is driven by middlemen, i.e., all available labor will go into the collecting activities on the arrival of these middlemen, irrespective of age and gender [13]. In contrast, due to gendered differences in education levels, language skills, and socioeconomic expectations, it is predominantly the young men who engage in off-farm employment (see [23]). NTFPs are only a moderately rewarding but low risk source of income for the population staying behind, notably women and elderly people. As arable land rather than labor is the limiting factor in agriculture, the costs of 
sending young and skilled household members to off-farm work are marginal, but the benefits are all the greater [28]: Household income can increase substantially without impacting on other livelihood activities (primary feedback with little interference with other livelihood activities), while at the same time the resilience of households is maintained, not only regarding economic diversification, but also with reference to cultural identity and social cohesion. Migrant labor is typically done for no longer than a couple of months per year and has no adverse long-term effects (secondary feedback loops) on the respective household's members, such as social alienation, financial dependence, or settling in the urban centers for good. Hence local social networks remain intact and relevant during times of rapid socioeconomic change, which strongly influences the social sustainability of the communities [33].

\section{Conclusions}

Income disparity between mountain and valley households largely disappeared within the past few years, indicating that the economy in Shaxi Valley and beyond is flourishing and creates income sources for the large majority of its households. The main drivers for this development are the local tourist industry, persistent demand for forest resources, and local off-farm and seasonal migrant employment. However, while in the valley villages the household members' education levels have continuously increased in the past decades, ensuring a broad diversification of livelihoods, education levels in the mountain villages remained very low. At the same time mountain livelihoods are highly dependent on forest resources susceptible to environmental change, over-collection, market price fluctuations, and engagement in low-skilled and insecure migrant labor. These vulnerable livelihoods do not appear to be resilient and sustainable until remote households are fully integrated into the educational system and are entitled to the compensation scheme for rendering ecosystem services in the context of the Sloping Land Conversion Program.

\section{Acknowledgments}

We are very grateful to the inhabitants of Shaxi Township for their openness and hospitality as well as to the local government in Sideng for the support of research in Shaxi. We thank Chen Yulin for his knowledgeable help in conducting the fieldwork, and Yang Yongping and Han Xi from the Kunming Institute of Botany, CAS, for their extensive support. Edwin Schmitt, Rolf Rutishauser, and two anonymous reviewers provided helpful comments on an earlier draft of the manuscript.

\section{Author Contributions}

Franz K. Huber and Caroline S. Weckerle initiated the project and with Klaus Seeland jointly structured the project and the paper. Franz K. Huber collected the data. Franz K. Huber and Michael Morlok analyzed the data. Franz K. Huber and Klaus Seeland led the writing. All authors have read and approved the final manuscript.

\section{Conflicts of Interest}

The authors declare no conflict of interest. 


\section{References}

1. Ives, J.D. Himalayan Perceptions: Environmental Change and the Well-Being of Mountain Peoples; Routledge: Oxon, UK, 2004.

2. Lenzen, M.; Peters, G.M. How City Dwellers Affect Their Resource Hinterland. A Spatial Impact Study of Australian Households. J. Ind. Ecol. 2009, 14, 73-90.

3. Seeborg, M.C.; Jin, Z.H.; Zhu, Y.P. The new rural-urban labor mobility in China: Causes and implications. J. Socio-Econ. 2000, 29, 39-56.

4. Ives, J.D.; Messerli, B. The Himalayan Dilemma: Reconciling Development and Conservation; Routledge: London, UK; New York, NY, USA, 1989.

5. Mahdi; Shivakoti, G.P.; Schmidt-Vogt, D. Livelihood Change and Livelihood Sustainability in the Uplands of Lembang Subwatershed, West Sumatra, Indonesia, in a Changing Natural Resource Management Context. Environ. Manag. 2009, 43, 84-99.

6. Goodman, D.S.G. The campaign to "Open up the West": National, provincial-level and local perspectives. China $Q$. 2004, 178, 317-334.

7. Lai, H.H. China's Western Development Program: Its rationale, implementation, and prospects. Mod. China 2002, 28, 432-466.

8. McNally, C.A. Sichuan: Driving capitalist development westward. China Q. 2004, 178, 426-447.

9. Urgenson, L.S.; Hagmann, R.K.; Henck, A.C.; Harrell, S.; Hinckley, T.M.; Shepler, S.J.; Grub, B.L.; Chi, P.M. Social-ecological Resilience of a Nuosu Community-linked Watershed, Southwest Sichuan, China. Ecol. Soc. 2010, 15, Article 2. Available online: http://www.ecologyandsociety.org/vol15/iss4/art2/ (accessed on 11 March 2015).

10. Scholz, R.W. Environmental Literacy in Science and Society: From Knowledge to Decisions; Cambridge University Press: Cambridge, UK, 2011.

11. Le, Q.B.; Seidl, R.; Scholz, R.W. Feedback loops and types of adaptation in the modelling of land-use decisions in an agent-based simulation. Environ. Modell. Softw. 2012, 27-28, 83-96.

12. Myers, N.; Mittermeier, R.A.; Mittermeier, C.G.; da Fonseca, G.A.B.; Kent, J. Biodiversity hotspots for conservation priorities. Nature 2000, 403, 853-858.

13. Huber, F.K.; Ineichen, R.; Yang, Y.P.; Weckerle, C.S. Livelihood and conservation aspects of non-wood forest product collection in the Shaxi valley, Southwest China. Econ. Bot. 2010, 64, 189-204.

14. Weckerle, C.S.; Ineichen, R.; Huber, F.K.; Yang, Y.P. Mao’s Heritage: Medicinal Plant Knowledge among the Bai in Shaxi, China, at a Crossroads between Distinct Local and Common Widespread Practice. J. Ethnopharmacol. 2009, 123, 213-228.

15. Morel, A.; Forster, D. Sideng Mission Report. Environmental Sanitation Survey July-August 2002; SANDEC/EAWAG: Duebendorf, Switzerland, 2002.

16. Yang, F.Q. The "Ancient Tea and Horse Caravan Road", the "Silk Road" of Southwest China. Silk Road 2004, 2, 29-33.

17. Katzen, J. Shaxi valley: Using history to address the future. In Tourism and Development in Yunnan; Mitchell, S., Ed.; Yunnan Fine Arts Publishing House: Kunming, Yunnan, China, 2003; pp. 174-215.

18. Feiner, J.P.; Mi, S.W.; Schmid, W.A. Sustainable Rural Development Based on Cultural Heritage: The Case of the Shaxi Valley Rehabilitation Project. DISP 2002, 151, 79-86. 
19. Scholz, R.W.; Binder, C. Principles of Human-Environment Systems (HES) research. In Proceedings of the Transactions of the 2nd Biennial Meeting of the International Environmental Modelling and Software Society, Manno, Switzerland, 14-17 June 2004; Complexity and Integrated Resources Management; Pahl, C., Schmidt, S., Rizzoli, A.E., Jakeman, T., Eds.; International Environmental Modelling and Software Society: Manno, Switzerland, 2004; pp. 791-796.

20. Pahl-Wostl, C. A conceptual framework for analysing adaptive capacity and multi-level learning processes in resource governance regimes. Glob. Environ. Chang. 2009, 19, 354-365.

21. DFID. Sustainable Livelihoods Guidance Sheets, Sections 1-7. Department for International Development, London, UK, 1999-2001. Available online: http://www.ennonline.net/resources/667 (accessed on 22 December 2014).

22. The World Bank. Data - Inflation, Consumer Prices. Available online: http://data.worldbank.org/ indicator/FP.CPI.TOTL.ZG (accessed on 22 December 2014).

23. Démurger, S.; Fournier, M.; Yang, W.Y. Rural households' decisions towards income diversification: Evidence from a township in northern China. China Econ. Rev. 2010, 21, S23-S44.

24. Block, S.; Webb, P. The dynamics of livelihood diversification in post-famine Ethiopia. Food Policy 2001, 26, 333-350.

25. Ersado, L. Income Diversification in Zimbabwe: Welfare Implications from Urban and Rural Areas. Available online: http://hdl.handle.net/10986/8389 (accessed on 11 March 2015).

26. Zhou, Y.Y.; Han, H.; Harrell, S. From Labour to Capital: Intra-Village Inequality in Rural China, 1988-2006. China Q. 2008, 195, 515-534.

27. Tilt, B. Smallholders and the "Household Responsibility System": Adapting to Institutional Change in Chinese Agriculture. Hum. Ecol. 2008, 36, 189-199.

28. Christiansen, F. Food Security, Urbanization and Social Stability in China. J. Agrar. Chang. 2009, 9, 548-575.

29. Binder, C.R.; Hinkel, J.; Bots, P.W.G.; Pahl-Wostl, C. Comparison of Frameworks for Analyzing Social-ecological Systems. Available online: http://dlc.dlib.indiana.edu/dlc/handle/10535/9198 (accessed on 11 March 2015).

30. Walker, B.; Holling, C.S.; Carpenter, S.R.; Kinzig, A. Resilience, Adaptability and Transformability on Social-ecological Systems. Available online: http://www.ecologyandsociety.org/ vo19/iss2/art5/ (accessed on 11 March 2015).

31. De Brauw, A.; Rozelle, S. Reconciling the returns to education in off-farm wage employment in rural China. Rev. Dev. Econ. 2008, 12, 57-71.

32. Wong, L. Chinese Migrant Workers: Rights Attainment Deficits, Rights Consciousness and Personal Strategies. China Q. 2011, 208, 870-892.

33. Huber, F.K.; Yang, Y.P.; Weckerle, C.S.; Seeland, K. Diversification of livelihoods in a society in transition: A case study of Tibetan communities in Southwest China. Soc. Nat. Resour. 2014, 27, 706-723.

34. Harrell, S.; Aga, R. Education or Migrant Labor: A New Dilemma in China's Borderlands. Available online: http://www.japanfocus.org/-Stevan-Harrell/3939 (accessed on 11 March 2015).

35. Gurung, D.B.; Seeland, K. Ecotourism Benefits and Livelihood Improvement for Sustainable Development in the Nature Conservation Areas of Bhutan. Sustain. Dev. 2011, 19, 348-358. 
36. Müller-Böker, U; Kollmair, M. Livelihood Strategies and Local Perceptions of a New Nature Conservation Project in Nepal. Mt. Res. Dev. 2000, 20, 324-331.

37. Zhang, L.P.; Zhang, Y.L.; Yan, J.Z.; Wu, Y.Y. Livelihood diversification and cropland use pattern in agro-pastoral mountainous region of eastern Tibetan Plateau. J. Geogr. Sci. 2008, 18, 499-509.

38. Hedge, R.; Enters, T. Forest products and household economy: A case study from Mudumalai Wildlife Sanctuary, Southern India. Environ. Conserv. 2000, 27, 250-259.

39. Kar, S.P.; Jacobson, M.G. NTFP income contribution to household economy and related socio-economic factors: Lessons from Bangladesh. For. Policy Econ. 2012, 14, 136-142.

40. He, J.; Dong, M.; Stark, M. Small Mushrooms for Big Business? Gaps in the Sustainable Management of Non-Timber Forest Products in Southwest China. Sustainability 2014, 6, 6847-6861.

(C) 2015 by the authors; licensee MDPI, Basel, Switzerland. This article is an open access article distributed under the terms and conditions of the Creative Commons Attribution license (http://creativecommons.org/licenses/by/4.0/). 